\title{
HOOLIGANS, HIPPIES, AND IMMATURE YOUTH: NEGOTIATING COMMUNIST PARTY NARRATIVES OF MAY 18, 1972 IN KAUNAS
}

\author{
Amanda Jeanne Swain
}

ABSTRACT In the aftermath of the street demonstrations in Kaunas in May 1972, Communist Party leaders developed a narrative of the events that downplayed nationalism or political dissent as motivating factors for the unrest. Initially, Soviet authorities blamed marginal elements in society, specifically hooligans and hippies, for instigating what they called a 'disturbance of public order'. However, the demographics of participants forced Party leaders to explain why young people who were students, workers and even Komsomol members would take to the streets shouting slogans such as 'Freedom for Lithuania' and 'Freedom for hippies'. As a result, the Communist Party focused on the failure to inculcate Soviet youth with proper ideological values, making them susceptible to manipulation by 'hostile elements'. In doing so, Party leaders were able to use the political practice of self-criticism to keep the events of May 1972 within acceptable ideological bounds. However, the recognition of its own weaknesses did not stop the Lithuanian Communist Party from blaming other groups, such as parents, schools and cultural organizations, for failing to provide a proper upbringing for Soviet Lithuanian youth. Although cultural and intellectual organizations were only one of the factors blamed for the political immaturity of youth and their susceptibility to corrupting influences, they were the ones to suffer the consequences of the Soviet authorities' crackdown after the street demonstrations. Through a process of applying and discarding various discursive options, Lithuanian communist officials were able to use Soviet ideological narratives to protect themselves from criticism and to eliminate disruptive cultural and intellectual leaders in Kaunas.

On 14 May 1972, 19-year-old Romas Kalanta burned himself in the centre of Kaunas, in front of the Musical Theatre. Two thousand people, mainly in their late teens and early twenties, engaged in street demonstrations on 18 May, the day of his funeral, in one of the largest incidents of popular protest in Soviet Lithuania. On the following day, fifteen hundred people again protested in the 
centre of Kaunas. In the aftermath of the street demonstrations, the Communist Party in Lithuania (CPL) sought to understand the causes of the events of Thursday 18 May, and Friday 19 May 1972. CPL reports and speeches reveal that initial attempts by the Party leadership to conceptualize the events as the actions of marginal elements in Soviet society were ideologically constrained by official discourses of criminality and Cold War politics. In their attempt to explain the nature of the unrest, the character of the participants, and the cause of their participation, communist officials consciously rejected nationalism as a cause and instead blamed hooligans and hippies. However, the demographics of the youth who were arrested forced the communist leadership to negotiate discursive possibilities in order to explain why school and university students, including Communist Youth League (Komjaunimas) members, would engage in street demonstrations. As a result, Soviet authorities used the political practice of self-criticism to identify the participants as 'politically unaware youth', situating the events in Kaunas within the broader context of Soviet 'youth problems' and at the same time denying young people the capacity to express discontent with the Soviet system. Party officials used these accepted political practices to mitigate the consequences of the street demonstrations by defining them in more acceptable terms, given the domestic and international conditions of the Soviet Union in 1972.

Although the May 1972 events are frequently discussed in the Lithuanian popular press, Kalanta's death and the ensuing street demonstrations have received limited attention by scholars of Lithuanian or Soviet history. When they are mentioned in English-language works on the Soviet Union, the 1972 events in Kaunas are cited as examples of nationalist and/or anti-Soviet feeling in the Lithuanian Soviet Socialist Republic (LiSSR), yet without an analysis of their origins or of their deeper political and social consequences ${ }^{1}$. The

${ }^{1}$ Examples include: L. Alexeyeva, Soviet Dissent: Contemporary Movements for National, Religious, and Human Rights, (Middletown, CT, 1985); M. Beissinger, Nationalist Mobilization and the Collapse of the Soviet State (Cambridge, 2002); B. Fowkes, The Disintegration of the Soviet Union: A Study in the Rise and Triumph of Nationalism (New York, 1997). V. Kozlov's extensive work on popular protest in the Soviet Union does not mention the 1972 events in Kaunas. V.A. Kozlov, Mass Uprisings in the USSR: Protest and Rebellion in the Post-Stalin Years, tr. E. McClarnand MacKinnon (London; Armonk, NY 2002). The only work to provide an extended analysis of Kalanta's death is V. Stanley Vardys, The Catholic Church, Dissent and Nationality in Soviet Lithuania (Boulder, 1978). However, Vardys did not have access to the majority of sources used in my research. 
main scholarly work on Kaunas May 1972 was conducted for a conference at Vytautas Magnus University in 2002 on the 30th anniversary of the events. Articles from the conference were published in the 2003 issue of Kauno Istorijos Metraštis. Scholars assessed the various aspects of the May 1972 street demonstrations, including KGB accounts of the events, the CPL's response, the response in the West and the relationship between cultural and ideological movements in the West and the events in Kaunas ${ }^{2}$. Additionally, an article on the KGB response to the May 1972 events was published in $2003^{3}$.

In his analysis of the KGB's response to Kalanta's self-immolation and the ensuing street demonstrations, Arvydas Anušauskas argues that the Soviet authorities prosecuted participants as 'hooligans' in order to depoliticise what happened on the streets in Kaunas. Rather than acknowledging discontent by 'nonconformist' youth or nationalist sentiment, the KGB chose to label the events as the work of petty criminals ${ }^{4}$. Kastytis Antanaitis demonstrates the strong domestic and international pressures on the Lithuanian authorities to downplay the unrest that had occurred in the republic. The CPL leadership did not want to provoke criticism from Moscow nor did it want to cause tensions in the détente between the USSR and the USA by exposing popular discontent in the Soviet Union ${ }^{5}$. As Rytis Bulota shows, local communists also wanted to de-emphasize the cultural and ideological influences of the West in Soviet Lithuanian society for the same reasons ${ }^{6}$. This article contributes a more in-depth analysis of the process by which Lithuanian communist officials used official Soviet narratives to produce an account of

${ }^{2}$ Articles include B. Genzelis, 'Psichologinis lūžis ir valdžia'; N. Gudaitis, 'R. Kalantos ịvykių atgarsiai Lietuvoje pagal KGB operatyvinę informaciją'; R. Tverkutè, '1972 metų gegužès ịvykiai liudininkų akimis'; A. Jakubčionis, ‘1972-ujju metų Kauno reminescencijos’; L. Saldukas, '1972 metų Kauno ịvykių atspindžiai išeivijos spaudoje'; and K. Fuchs, 'The Death of Romas Kalanta in the Contemporary West European Press', Kauno Istorijos Metraštis, 4 (Kaunas, 2003). These works provided an important foundation for the author's research on the 1972 street demonstrations.

${ }^{3}$ A. Anušauskas, 'KGB reakcija ị 1972 ịvykius', Genocidas ir Rezistencija, vol. 13, no. 1 (2003), pp. 80-83.

${ }^{4}$ Ibidem.

${ }^{5}$ K. Antanaitis, 'Sovietinių partinių institucijų reakcija ị 1972 įvykius Kaune', Kauno Istorijos Metraštis, 4, pp. 15-26.

${ }^{6}$ R. Bulota, '1972 metų ịvykiai Kaune šaltojo karo kontekste ir jų ịtaka lietuviškai kultūrai’, Kauno Istorijos Metraštis, 4, pp. 111-117. 
the events of May 1972 that enabled them to depoliticise the street demonstrations. It also explains why the purge of intellectual and cultural leaders in Kaunas, documented by Antanaitis, became a logical response to the street demonstrations carried out by youth.

Internal CPL reports and speeches produced during the four weeks after Kalanta's self-immolation and the ensuing unrest provide evidence that Communist Party officials sought an ideologically satisfactory interpretation of the popular unrest that followed Kalanta's funeral. In response to information from the KGB on the demographics of the young people who participated in the demonstrations, Communist party officials constructed a narrative that identified politically immature young people spurred to anti-social actions in the form of rioting by anti-Soviet and nationalist elements, in particular the 'so-called hippies'. This characterization of young people as unthinkingly manipulated by outside forces rejected an interpretation of the events as a manifestation of real discontent.

A series of documents produced in the weeks after the street demonstrations - a 20 May report on the measures taken by the Party in response to the events, a May report to the CPL Central Committee summarizing the events, a 30 May Ordinance outlining measures to be taken in light of the events, speeches from a 2 June meeting of Party activists, and a 14 June speech by First Secretary Antanas Sniečkus to Party activists - demonstrate how the Communist Party's interpretation of the events changed over time.

A close analysis of these documents reveals that Party officials' interpretation of the nature of the unrest, the character of the participants, and the cause of their participation transitioned from blaming hooligans to blaming hippies to attributing the unrest to politically immature young people. The documents refer to nationalist, antiSoviet and foreign bourgeois elements taking advantage of the events, yet they do not designate these as the primary causes. While this narrative seems clear cut on the surface, it is fraught with ambiguity. Each interpretation in the documents - hooligans, hippies, and politically immature youth - had particular consequences for the political and social environment in Kaunas and for the Communist Party as the ideological vanguard. Initially, communist officials had to explain what brought young people out into the streets in response to Kalanta's self-immolation. Once the narrative based on politically immature youth had been constructed, they had to explain the causes of political immaturity among young people in Kaunas. The CPL 


\begin{tabular}{|c|c|c|}
\hline Designation & Title & Date \\
\hline May 20 report & $\begin{array}{l}\text { 'Information About Measures Taken } \\
\text { and Actions Taken by the Kaunas } \\
\text { Gorkom and the City Raikoms of } \\
\text { the Communist Party of Lithuania } \\
\text { in Connection with the Events in the } \\
\text { City of Kaunas on 14-19 May 1972'1 }\end{array}$ & $\begin{array}{l}\text { May 20, } \\
1972\end{array}$ \\
\hline Summary report & Untitled summary of events ${ }^{2}$ & $\begin{array}{l}\text { May 24?, } \\
1972^{3}\end{array}$ \\
\hline May 30 Ordinance & $\begin{array}{l}\text { 'Ordinance Concerning the Need to } \\
\text { Strengthen Political and Administra- } \\
\text { tive Work in Connection with the An- } \\
\text { ti-Social Developments in the City of } \\
\text { Kaunas'4 }\end{array}$ & $\begin{array}{l}\text { May 30, } \\
1972\end{array}$ \\
\hline June 2 speeches & $\begin{array}{l}\text { Protocol No. } 3 \text { Meeting of City Party } \\
\text { Activists }^{5}\end{array}$ & June 2, 1972 \\
\hline Sniečkus speech & $\begin{array}{l}\text { Transcripts of Meeting of CPL Activ- } \\
\text { ists }^{6}\end{array}$ & $\begin{array}{l}\text { June 14, } \\
1972\end{array}$ \\
\hline
\end{tabular}

1 'Информация о принятых мерах и проведенных мероприятиях Каунасским горкомом и горраикомами КП Литвы связи с происшествиями в городе Каунасе 14-19 Мая 1972 г.' [Information About Measures Taken and Actions Taken by the Kaunas Gorkom and the City Raikoms of the Communist Party of Lithuania in Connection with the Events in the City of Kaunas on 14-19 May 1972], Central Committee of the Communist Party of Lithuania, 20 May 1972. LYA, LKP Skyrius, f. 3110 , ap. 61, b. 34 .

2 (Untitled Summary Report), Central Committee of the Communist Party of Lithuania. May (24?), 1972. LYA, LKP Skyrius, f. 1771, ap. 247, b. 79.

${ }^{3}$ The memorandum is dated May 1972 but is located in a file labeled 'May 24, 1972' and other documents in the file are all labeled 'May 24'.

4 'Постановление бюро центрального комитета КП Литвы от 30 мая 1972 года' [Ordinance Concerning the Need to Strengthen Political and Administrative Work in Connection with the Anti-Social Developments in the City of Kaunas], Central Committee of the Communist Party of Lithuania, 30 May 1972. LYA, LKP skyrius, f. 1771, ap. 247, b. 79.

5 'Протокол No. 3 собрания партийного актива' [Meeting of City Party Activists], Communist Party of Lithuania, 2 June 1972. LYA, LKP skyrius, f. 3110, ap. 61, b. 15 .

6 'Оглавление материалов к протоколу и стенограмме заседаний собрания актива коммунистической партии Литвы' [Transcripts of Meeting of Communist Party of Lithuania Activists], Communist Party of Lithuania, 14 June 1972. LYA, LKP skyrius, f. 1771, ap. 247, b. 26. 
narrative of the events of 18-19 May downplayed explanations that might imply social and political agency on the part of the young people who participated in the demonstrations. Instead, the CPL's response emphasized its own failure to inculcate young people with the proper attitudes and values, a response grounded in the Soviet practice of self-criticism. In particular, the CPL emphasized the need to fulfill Soviet policies and values as articulated at the 24th Congress of the Communist Party of the Soviet Union a year earlier.

The Communist Party reports emphasized that hostile, anti-Soviet and anti-social elements provoked the crowd of young people into carrying out an anti-social manifestation. The summary report stated that 'Independent hostile individuals attempted to use the riots that they provoked for anti-Soviet purposes'. The 30 May Ordinance asserted that 'certain hostile elements' took advantage of the situation with the aim 'to give the events a political, anti-Soviet interpretation, allowing outcries, distributing flyers, and creating nationalist signs'. The report given on 2 June by Kaunas First Secretary Kazimieras Lengvinas noted that 'the chanting of various anti-Soviet and nationalistic slogans and pamphlets tell us that it is not out of the question that some of the elements trying to take advantage of Kalanta's self-immolation for anti-social and nationalistic reasons are factions in the city which are hostile to the entire Soviet structure'. Additionally, a speech by Comrade Bagdonas, head of the Kaunas City Division of the KGB, on 2 June gave 'evidence' that nationalist and anti-Soviet elements were taking advantage of events: 'This is borne witness by the fact that immediately after a crowd of young people had spontaneously gathered, the various apolitical and hooliganish slogans they were chanting were followed by certain individuals shouting slogans of a nationalist and anti-Soviet character, such as "Freedom for Lithuania!", "Freedom!" and so forth"7.

\section{Blaming hooligans}

By identifying the people on the streets as hooligans in the 20 May report, Party officials attributed the unrest to marginal elements in society. The report characterised the people on the streets as 'rioters'

7 'Протокол No. 3' [Meeting of City Party Activists], 2 June, 1972. Bagdonas does not specify what the apolitical and hooliganish slogans are. However, eyewitness and participant statements in the KGB investigation files state that the crowd also shouted 'Down with the police [militsia] and their bananas!' and 'Hurrah!' 
and emphasised that participants in the unrest included hippies, 'a certain proportion of young non-cadre workers, a number of people with prior convictions and people who are not engaged in any kind of socially useful work'. Given the saturation of the concept of 'hooliganism' in the Soviet Union, it is not surprising that the popular unrest in Kaunas was immediately labeled as 'hooliganism'. After all, 2,000 young people in the streets refused to disperse when ordered to do so, and the crowd had to be broken up by police and volunteer brigades. According to the report,

On that same day, as riots began breaking out, the Party gorkom and raikoms called on workers cadres, Party-Agricultural and Komsomol activists, and the people's auxiliary police (around 300 people) to assist the police [militsia], and these people took an active part in expository work and in dispersing the hooligan youth. By midnight, public order had for the most part been restored ${ }^{8}$.

Additionally, the 20 May report provided quotes to demonstrate that 'cadre workers, university students, and the intelligentsia did not take part in the riots, and correctly evaluated the actions of the hooligan youth'. An assistant foreman and brigadier of a communist labour brigade at the Kaunas fabrics factory announced 'I condemn the actions of the hooligans. These impudent hooligan attacks must be put down!' A plumbing factory mechanic declared, 'We decisively condemn the hooligan actions of those who disturb our peace... To the hooligans, we give our decisive workers' "NO!" The report concluded with condemnations of the events of the previous two days by workers, a teacher and the director of the Musical Theater, all of whom emphasised the role of hooligans in 'disturbances of public order' 9 .

Confronted with statistics of those arrested for participating in the demonstrations, communist officials could no longer write off the events as the actions of marginalised elements in society. The summary report of the demonstrations included statistical data about the young people who were detained on 18 May from the KGB reports. The composition of the people who were arrested certainly

8 'Информация о принятых мерах и проведенных мероприятиях Каунасским горком и горраикомами КП Литвы связи с происшествиями второду Каунасе 14-19 Мая 1972 г.' [Information About Measures Taken and Actions Taken by the Kaunas Gorkom and the City Raikoms of the Communist Party of Lithuania in Connection with the Events in the City of Kaunas on 14-19 May 1972], 20 May 1972.

\footnotetext{
${ }^{9}$ Ibidem.
} 
differed from the characteristics put forth in the 20 May report. Only $5 \%$ of those arrested were unemployed. Nearly half $-48 \%$ - were workers, and more than one-third were students. Even more compelling, nearly one quarter $(24 \%)$ were Komsomol members. Once the KGB investigation revealed the demographics of the participants in the unrest, the language of hooliganism in CPL documents significantly decreased. In its description of the crowd that formed in the centre on 18 May, the summary report makes reference to 'certain criminal elements in the crowd' that engaged in vandalism, but these 'petty criminals' played a small role given the scale of the unrest. Instead, the report used 'anti-social' as the key descriptor of the young people involved in the unrest. In the June report and speeches, the term 'hooligans' was only used when describing public response to the events and not in descriptions of the young people on the street. For example, the 2 June report included the term 'hooligan' once in a statement that 'the absolute majority of the population... condemns the hooligans'. Similarly, speeches by the Communist Party leadership in June speeches commended the public for 'correctly interpreting' the unrest as the work of hooligans ${ }^{10}$. The arrest statistics contradicted initial statements that the crowd was composed of hooligans and forced Communist Party leaders to reconsider both who was involved in the popular unrest and why they would participate. In doing so, the CPL focused on a second marginalised group - hippies.

\section{Blaming hippies}

The summary report prepared by the CPL accused 'so-called hippies' for instigating the events and for corrupting young people. The report repeated a KGB allegation that local hippies plotted to steal Kalanta's body, giving this as the reason for changing the time of the funeral on 18 May. According to the report,

The Kaunas city division used active measures to obtain information pointing to the intent of the so-called 'hippies' to gather together a significant number of their adherents to carry the deceased's coffin to the graveyard, and thence to protest by marching across the city to the place of his self-immolation, lay flowers on the site, and hold a demonstration. Certain 'hippies' had expressed their intent to seize the body of the suicide victim from his parents by force ${ }^{11}$.

\footnotetext{
${ }^{10}$ Untitled Summary Report, (24?) May 1972.

${ }^{11}$ Ibidem.
} 
The report noted that the funeral services 'were carried out without incident' despite the threat. However, it accused 'certain active followers of the "hippie" movement' (specifically Vytautas Kalade and Antanas Kačinskas) of taking advantage of the crowd of young people who gathered at the Kalanta home at the originally scheduled time of the funeral and proposing a march to the city center. The 30 May Ordinance condemned the 'harmful influence of the so-called "hippie" followers, famous for their provocative disheveled appearance, known by their worship of the West, desire for vagrancy and their anarchistic attitude'. While young people who manifested such a lifestyle were also marginal elements in Soviet society, Komsomol Secretary Poškus distinguished hippies from hooligans. He identified hippies as a problem due to their stance toward the Soviet system rather than their disruptive behaviour. He asserted that the hippies 'rarely engage in hooliganism and drunkenness, however, they are apolitical, and have a harmful effect on other young people" 12 .

The summary report provided a preliminary conclusion that quoted directly from the KGB's report on the causes of the street demonstrations: "the initial instigators and active participants of the mass anti-social demonstrations were young individuals, who mimicked the 'so-called "hippie" movement'. Young people's desire to follow hippies had become a problem because 'until recently, not enough attention has been paid by Soviet, Komsomol, and administrative organs to monitoring the activities of anti-social elements and those who would emulate the "hippie" movement, weak efforts have been made to conduct preventative propaganda efforts among them, and at the same time no warning was given about the harmful tendencies that have been developing among them'13.

Like the attempt to accuse hooligans for the disturbance of public order, the designation of hippies as the culprit was undermined by the demographics of the young people on the streets, most of whom were not actively involved in the small Kaunas hippie movement. By early June, CPL officials emphasized not the hippies themselves

12 'Постановление бюро центрального комитета КП Литвы от 30 мая 1972 года' [Ordinance Concerning the Need to Strengthen Political and Administrative Work in Connection with the Anti-Social Developments in the City of Kaunas], 30 May 1972.

13 (Untitled Summary Report), (24?) Мау 1972. 'Справка' [Memorandum], Коммитет государственной безопасности Литовской CCP [LitSSR KGB], 1972? LYA, KGB Skyrius, f. K-1, ap. 3, b. 793, pp. 142-149. 
but young people who were unduly influenced by hippies in order to explain the massive number of young people on the streets. The 2 June speech by Lengvinas no longer referred to hippies, but instead identified the participants in the demonstrations as "young people who did not understand the significance of their actions and who had fallen for the provocations of "hippies" and similar elements'. This also marked a change from blaming active agents of unrest to blaming young people who were manipulated rather than expressing their own discontent.

\section{Blaming politically immature youth}

The Communist leadership turned to the ideological upbringing of youth in order to understand why young people - especially those who were part of the Soviet system as workers, university and secondary school students, and Komsomol members - were susceptible to hippie influence. During the weeks after the 18-19 May demonstrations, the term 'unthinking' (or 'unaware') was used with increasing frequency to describe the young people on the streets. In the 20 May report, the term was used only once. The summary report emphasized that the crowd that gathered at the Kalanta home and carried out the 'massive anti-social demonstration' was primarily comprised of young people and concluded by labeling the young people, as 'politically immature'. The 30 May Ordinance emphasized that the young people held a 'politically incorrect outlook and attitude that is foreign to Soviet society'. Communist authorities also noted that the young people themselves did not consider their actions to be anti-Soviet, which demonstrated that they were unaware of what constituted proper behaviour. In his speech on 2 June, Comrade Poškus, the head of the Lithuanian Communist Youth Organization, said 'we have encountered cases where young students do not know and do not understand what political vigilance and commitment to principle mean. They connect, judging by what they themselves say on the issue, anti-Soviet activities with mere bad behaviour' ${ }^{14}$.

By 2 June, Communist Party officials had completely moved away from the language of 'hooliganism' and instead attributed political immaturity as the defining characteristic of the young people on the street on 18-19 May. While various anti-social elements were a part of the events - hooligans and hippies specifically - their

14 'Протокол No. 3’ [Meeting of City Party Activists], 2 June 1972. 
success in disturbing the public order was due to the political immaturity of young people who then fell under their influence. In his speech to the Party activists on 2 June, Kaunas Communist Party Secretary Lengvinas stated that the main participants in the 'largely spontaneous' riots were 'young people who did not understand the significance of their actions'. The events were therefore classified as "violations of public order and hooligan actions of a group of immature young people'. Lengvinas also spoke about the 'anti-social demonstrations and the hooliganish actions of a group of politically immature people' ${ }^{15}$. In this narrative of the events, the young people on the streets were not hooligans; rather their immaturity led them to hooligan-type actions.

In the view of the Communist Party officials, the street demonstrations following Kalanta's self-immolation were representative of a broader 'youth problem' and not an isolated event. The 30 May Ordinance put the events of 18-19 May in the context of other incidents in which youth 'behaved in a disorderly and undisciplined manner at music concerts, basketball games, boxing matches and other events'16. In his 2 June speech, Poškus emphasized that 'the majority of the city's young people has been, is now, and will continue to be faithful to their class duties in their daily work and affairs, proving their allegiance to the work of the Communist Party'. He commended the participation of young people from Soviet Lithuania in the march 'Through the places of Revolutionary, Labor and Military Glory of the Communist Party and the Soviet People', which was praised by General Secretary Leonid Brezhnev at the Communist Party of the Soviet Union's 24th Party Congress. However, he continued that

we cannot close our eyes to the problems which have arisen in that work. We encounter cases where certain young people are taken in by the stream of antiSoviet lies which have infiltrated via various channels and follow the incorrect path, infecting others with their anti-Soviet mood. In re-examining the information we have collected in recent years in the city, it has become clear that the largest

${ }^{15}$ Ibidem.

16 'Постановление бюро центрального комитета' [Ordinance Concerning the Need to Strengthen Political and Administrative Work in Connection with the AntiSocial Developments in the City of Kaunas], 30 May, 1972. Although the speech does not identify specifics, incidents that fit this list have been reported in other sources. For example, disturbances followed a boxing match between Lithuanian and Uzbek teams in July 1960. R.J. Misiunas and R. Taagepera, The Baltic States: Years of Dependence, 1940-1990, 2nd ed. (Berkeley, 1993). 
number of apolitical and hooliganish attacks are carried out by students of general education and professional technical schools, and in certain cases, by university students and working young people. It is undesirable to cite concrete examples, in that they are all similar ${ }^{17}$.

For the Soviet authorities, the demonstrations that followed Kalanta's self-immolation were simply the largest manifestation of an ongoing problem of youth misbehavior.

The Communist Party also defined what the street demonstrations were not. The authorities rejected nationalist, class and generational conflicts as causing 2,000 young people to take to the streets in Kaunas. The reports and speeches expressed concern that an 'antisocial' outburst had the capacity to become 'anti-Soviet'; even so, this was seen as a result of manipulation by 'anti-Soviet and nationalist elements' rather than as a sentiment expressed by the participants in the mass unrest. Given that the KGB documents used 'nationalist', 'anti-social' and 'anti-Soviet' without clear distinction, there appears to have been a conscious choice on the part of communist officials not to label the demonstrations or demonstrators as nationalist or anti-Soviet. As both Antanaitis and Bulota demonstrated, Cold War politics had a strong influence on the CPL's response to the street demonstrations. The events in Kaunas were already being reported in the West as an anti-Soviet and nationalist action. ${ }^{18}$ In fact, the speeches by communist officials on 2 June referred directly to foreign elements and émigrés who were maligning the Soviet Union by claiming that the Kaunas unrest was anti-Soviet and nationalist in nature. The visit of United States President Richard Nixon, which occurred immediately after the Kaunas events, presented another reason to downplay what might be perceived as evidence of disaffection with the Soviet system ${ }^{19}$.

In its attempt to deny that nationalist or class tensions were the cause of the unrest, the Communist Party acknowledged the diversity of young people involved in the demonstrations. In a speech on 2 June, Comrade Guiga, First Secretary of the Kaunas district Party organisation, denied that the demonstrations had a nationalist character, 'inasmuch as the majority of participants were young men

17 'Протокол No. 3’ [Meeting of City Party Activists], 2 June 1972.

${ }_{18}$ H. Smith, 'Some Cracks in the Kremlin Wall', New York Times, 28 May 1972. K. Fuchs, 'The Death of Romas Kalanta in the Contemporary West German Press', Kauno Istorijos Metraštis, 4, (2003).

${ }^{19}$ Nixon's visit, the first by a US President to the Soviet Union, occurred 22-29 May. 
of Lithuanian nationality, but there were also Russians, Jews, and others'. Guiga also emphasised that the events of 18-19 May 'in no way bears a class character... Among those who participated in the violation of public order there were young workers, students, the children of workers and service people, and even of kolkhoz workers, because most of the students from professional and technical schools come from rural areas' ${ }^{20}$. Despite Guiga's assurances that the crowd's diversity was not indicative of splits in Soviet society, evidence that the participants came from such diverse ethnic and class backgrounds potentially indicates widespread discontent on the part of young people in Soviet Lithuania.

'Really existing socialism' was another ideological constraint within which the CPL had to work as it crafted a narrative of the events of 18-19 May. Communist officials clearly distinguished youth problems in contemporary Soviet society from those in Western capitalist societies. Guiga stated that "Although some degree of disagreement is to be expected between children and their parents, and between younger people and older people, there exists no disagreement whatsoever about the fundamental issues of life and politics, and there is no such thing as a generation gap in our society'. Guiga admitted that 'relics from the past' do exist and that 'these relics are transmitted to young people by some parents and others around them, and from older people. Bourgeois propaganda also has some effect on the minds of young people'. While he blamed 'relics' for the incidents of 'nationalism, alcoholism, theft, hooliganism, and anti-Soviet demonstrations' that did occur in Soviet Lithuania, Guiga did not explicitly blame the 'relics' for the events in Kaunas. Yet after so clearly eliminating nationalist, class and generational conflicts as causes, the Communist Party still had to explain why 2,000 young people would take to the streets chanting slogans such as 'Freedom for Lithuania' and 'Freedom for hippies'.

\section{The practice of self-criticism}

If the composition of the crowd meant that the authorities could not blame hooligans or hippies as they had initially attempted to do, the decision to identify politically immature youth as the cause of the popular unrest was rooted in the discursive possibilities available to Communist Party officials. The characterisation of the participants as

20 'Протокол No. 3' [Meeting of City Party Activists], 2 June 1972. 
young people whom the educational and Party structures had failed to properly inculcate with Soviet norms and values was consistent with the Soviet practice of self-criticism. Self-criticism as a Soviet practice rarely referred to an individual Party member's activity; rather self-criticism involved 'collective criticism by Party members of the weaknesses of the Party'. It involved an often perfunctory claim that the flaws resulted in part 'not having worked enough'. As the vanguard in the transformation of Soviet society and the only party in the Soviet Union, the Communist Party alone had the responsibility for identifying and eliminating its own flaws ${ }^{21}$. This style of self-criticism is evident in the CPL's response to the popular unrest, beginning with the 30 May Ordinance which listed a series of actions to be taken as a result of the events.

The Kaunas Party organization was criticised for a number of failures in the political indoctrination of young people. The 30 May Ordinance stated that 'significant transformations have taken place in the city of Kaunas during the years of Soviet power... Nevertheless, the recent unfavourable developments bear witness to the presence of considerable flaws in the work of the Kaunas City Party Organisation'. The report condemned the city and district Party committees for failing to 'pay sufficient attention to developing a deep ideological conviction and political tenacity within young people or the workforce'. The report specifically blamed 'considerable flaws in the educational indoctrination work in schools and universities, but especially in public and vocational schools'. It also criticized the Kaunas Party, Komsomol and various other organisations for failing "to take the necessary measures to expose and interrupt... the harmful influence of the so-called "hippie" followers" 22 .

CPL leaders engaged in the practice of self-criticism in their speeches at the 2 June Party activists' meeting. Secretary of the Party organization at the P. Zibertas silk factory, Comrade Yakovlev, remarked that the Party 'cannot comfort ourselves with the thought that these riots arose spontaneously' and called on Party activists to examine carefully who took part in the unrest. In his 2 June speech,

${ }^{21}$ O. Kharkhordin, The Collective and the Individual in Russia: A Study of Practices (Berkeley, 1999), pp. 145-146.

22 'Информация о принятых мерах и проведенных мероприятиях' [Information About Measures Taken and Actions Taken by the Kaunas Gorkom and the City Raikoms of the Communist Party of Lithuania in Connection with the Events in the City of Kaunas on 14-19 May 1972], 20 May 1972. 
Guiga concluded that deficiencies in political and indoctrinational work were the mains reason for the young people's susceptibility to the influence of bourgeois propaganda and violated public order. At the same meeting, Bagdonas asserted that the lack of sufficient indoctrination was 'one of the primary reasons why the participants in the street riots in Kaunas were primarily young people studying in general education schools or professional technical institutes' ${ }^{23}$.

The Communist Party leadership also framed its self-criticism as a renewed commitment to fulfill the mandates of the 24th CPSU Congress. In his 14 June speech, Sniečkus reminded Party activists that

at the fifth plenary meeting of the Central Committee of the Communist Party of Lithuania, problems connecting to the further development of national education in the republic were discussed holistically in light of the 24th Congress of the CPSU. The resolutions that were passed call for concrete measures to be taken to further improve the education and indoctrination of the generation currently reaching adulthood. However, those decrees are not yet everywhere being made a reality in the way that they should be.

By referring to Soviet concerns about the indoctrination of youth, Sniečkus clearly situated the events in Kaunas within a broader context of Soviet social and political practices rather than specifically a problem of Lithuanian nationalism.

The Soviet practice of self-criticism was grounded in the collective, which served the wider interests of society ${ }^{24}$. Lengvinas, first secretary of the Kaunas Communist Party, emphasized the failure of the collective to respond strongly to evident youth problems. He condemned the leadership of the Communist Party and Komsomol, as well as schools and universities, for being 'indecisive in eliminating shortcomings in the education and indoctrination of students' and for frequently failing 'to respond to apathy, passivity, poor academic performance, and violations of public order'. He called for 'a serious re-examination of the condition of indoctrinational work in schools and universities'. Lengvinas demanded that those responsible for the political indoctrination of young people actively work 'against political apathy, the idealisation of the past, and a nihilistic view of the victories of Socialism'. He also connected political immaturity with tolerance for Western cultural practices. According to Lengvinas, 'the esthetic and moral indoctrination of

23 'Протокол No. 3' [Meeting of City Party Activists], 2 June 1972.

${ }^{24}$ For a thorough analysis of the role of the collective in Soviet ideology and society, see Kharkhordin, The Collective and the Individual. 
students must be improved fundamentally. An unkempt appearance, admiration for the West, and support for "hippies" cannot be tolerated in our schools and universities' 25 .

In the Communist Party leadership's view, the young people's actions on 18-19 May represented a failure of proper integration into the collective. In his 2 June speech, Lengvinas stated that 'youth must realize that the rights that our social order gives them are inseparably coupled with an obligation to carry out their duties, and with responsibility to their collective and to their society'. Similarly, Comrade Poškus, the head of the LiSSR Komsomol, expressed his opinion that the failure to integrate young people into the collective was the reason for the increase in the number of hippies in Kaunas. He stated that, "it was only the insufficient attention paid to them by Komsomol organisations, as well as other social organisations, that led them to tearing themselves away from their collective, and made it possible for them to unite themselves into separate groups ${ }^{26}$.

The Communist Youth Organisation had particular cause for self-criticism given that $24 \%$ of the young people arrested were Komsomol members. In his speech on 2 June, Poškus admitted that

the basic problem is the fact that Komsomol workers and Komsomol activists have a poor understanding of the popular mood of young people... We must openly admit that in certain cases we are doing ourselves more harm than good, fearing to speak openly about individual cases of apolitical attitudes or anti-Soviet hijinks and give them a principled Komsomol evaluation... Of course, in this case, blame falls on Komsomol workers and the Komsomol activists.

However, Poškus attempted to spread responsibility more broadly. He noted that 'blame must also fall on the leaders of academic groups and class leaders', who lacked the proper ideological knowledge to instruct young people.

Communist Party officials also held parents responsible for the problem of politically immature youth. In his speech on 14 June, CPL First Secretary Sniečkus stated that even the 'children of communists and responsible workers behave in an improper manner, poorly conduct themselves, and dress in a slovenly manner, and yet the parents bear absolutely no Party responsibility'. He accused parents of 'providing their children with a ruble or two of pocket money, without taking an interest in how the children are spending that money'.

25 'Протокол No. 3' [Meeting of City Party Activists], 2 June 1972.

${ }^{26}$ Ibidem. 
Sniečkus pointed out that parents 'do not demand that their children return home from school at any particular time. Thus, it is possible to encounter a fairly large number of teenagers on the streets and in parks at 11:00 and even after 12:00 at night'27.

In a similar vein, Yakovlev denounced young people whose 'standard of living is too high, they are allowed too many rights and freedoms 28 .

The journal Nemunas, theaters and social clubs in Kaunas, all of which had taken advantage of post-Stalin liberalisations, were also blamed for contributing to the improper behaviour of young people. In his 2 June speech, Bagdonas rebuked the city for playing host to pop-culture ensembles that 'do not always aid in the indoctrination of high esthetic, moral, and political values into young people'. He singled out the Kaunas State Drama Theatre for not being 'sufficiently conscientious in their choice of repertoire'. According to Bagdonas,

several plays, such as 'Hunting for Mammoths', 'A New One Has Come', 'Barbora Radvilaite' and others are ideologically weak, and sometimes, in effect, even ideologically harmful to some degree. Such performances have enabled the arousal and activation of politically unhealthy moods among certain members of the audience ${ }^{29}$.

Bagdonas also criticised the pantomime troupe based at the Kaunas Musical Theatre and its director Modris Teninsons. He accused the troupe for behaving amorally, supporting hippies, and giving 'voice to unhealthy opinions in front of audiences' ${ }^{30}$. Bagdonas similarly targeted the cultural journal Nemunas. Although he acknowledged that the journal contained useful material, he pointed out that certain articles did not 'help to properly indoctrinate young people'. In fact, he asserted, 'a tendency has been observed of these articles giving a one-sided exposition of problems in the life of young people in the West, without including a deep analysis and an evaluation of the problems based on Marxist positions' ${ }^{31}$. Sniečkus also blamed local theatres and the journal Nemunas for fomenting inappropriate values and behaviour. In his 14 June speech, Sniečkus noted that the journal had been criticized at previous meetings of Party activists but

27 ‘Оглавление материалов к протоколу’ [Transcripts of Meeting of Communist Party of Lithuania Activists], Communist Party of Lithuania, 14 June 1972.

28 'Протокол No. 3' [Meeting of City Party Activists], 2 June 1972.

${ }^{29}$ Ibidem. Jonas Jurašas, the Kaunas State Drama Theatre director, who staged these plays, was forced to emigrate to the United States after the May 1972 events.

${ }^{30}$ The pantomime troupe was disbanded after the May 1972 events, and Modris Teninsons returned to Riga.

${ }^{31}$ The journal Nemunas was temporarily closed down after the May 1972 events. 
it 'just keeps pumping out low-quality, trashy materials' ${ }^{32}$. By tying the street demonstrations directly to the activities of local cultural organizations, the communist authorities were able to justify taking actions to close down activities that were deemed unacceptable.

\section{Conclusion}

In the aftermath of the street demonstrations in Kaunas in May 1972, Communist Party leaders developed a narrative of the events that downplayed nationalism or political dissent as motivating factors for the unrest. Initially, Soviet authorities blamed marginal elements in society, specifically hooligans and hippies, for instigating what they called a 'disturbance of public order'. However, the demographics of participants forced Party leaders to explain why young people who were students, workers and even Komsomol members would take to the streets shouting slogans such as 'freedom for Lithuania' and 'freedom for hippies'. As a result, the Communist Party focused on the failure to inculcate Soviet youth with proper ideological values, making them susceptible to manipulation by 'hostile elements'. In doing so, Party leaders were able to use the political practice of self-criticism to keep the events of May 1972 within acceptable ideological bounds. However, the recognition of its own weaknesses did not stop the Lithuanian Communist Party from blaming other groups, such as parents, schools and cultural organizations, for failing to provide a proper upbringing for Soviet Lithuanian youth. Although cultural and intellectual organisations were only one of the factors blamed for the political immaturity of youth and their susceptibility to corrupting influences, they were the ones to suffer the consequences of the Soviet authorities' crackdown after the street demonstrations ${ }^{33}$. Through a process of applying and discarding various discursive options, Lithuanian communist officials were able to use Soviet ideological narratives to protect themselves from criticism and to eliminate disruptive cultural and intellectual leaders in Kaunas.

32 'Оглавление материалов к протоколу' [Transcripts of Meeting of Communist Party of Lithuania Activists], Communist Party of Lithuania, 14 June 1972.

${ }^{33}$ Antanaitis, 'Sovietinių partinių institucijų reakcija'. 
Author Details

Dr Amanda Jeanne Swain, Department of History, University of Washington

Email: ajswain@u.washington.edu

\title{
CHULIGANAI, HIPIAI IR NESUBRENDĘS JAUNIMAS: APTARIANT KOMUNISTŲ PARTIJOS 1972 M. GEGUŽĖS 18 D. KAUNO İVYKIŲ KOMENTARUS
}

\author{
Santrauka
}

AMANDA JEANNE SWAIN

Po 1972 m. gegužès demonstracijų Kauno gatvèse komunistų partijos vadai sukūre tokị įvykių paaiškinimą, kuris sumenkino nacionalizmo ar politinio nepritarimo įtaką neramumų kilimui. Iš pradžių sovietų valdžia kaltino „visuomeninès tvarkos pažeidimo“ kurstymu marginalinius visuomenès elementus - chuliganus ir hipius. Vis dèlto dalyvių kilmès ịvairovè verte partijos vadovus paaiškinti, kodèl jauni žmonès, kurie buvo studentai, tarnautojai ir net komjaunimo nariai, išèjo ị gatves su tokiais šūkiais kaip „Laisvę Lietuvai“ ar „Laisvę hipiams“. Dèl to komunistų partija surado paaiškinimą, kad tai buvusi nesėkmingo tikrųjų ideologinių vertybių diegimo sovietiniam jaunimui pasekmè, atvèrusi kelią „priešiškiems elementams“ manipuliuoti jaunimu. Šitaip partijos lyderiai pasinaudojo politine savikritikos praktika, kuri leido 1972 m. gegužès ịvykius vertinti pagal priimtiną ideologiją. Vis dėlto savo silpnumo pripažinimas nesustabdė Lietuvos komunistų partijos nuo kaltinimų tėvams, mokykloms ir kultūrinėms organizacijoms, kurie esą nesugebejjo tinkamai išauklèti sovietinio jaunimo. Ir nors kultūrinès bei intelektualinès organizacijos buvo tik vieni iš kaltininkų dẻ jaunimo politinès nebrandos ir jų imlumo blogoms įtakoms, būtent jos labiausiai nukentejo nuo sovietų valdžios smūgių, prasidèjusių po gatvių demonstracijų. Lietuvos komunistų oficiozai sugebejo pasinaudoti sovietų ideologijos naratyvais, siekdami apsisaugoti nuo kritikos ir pašalinti jiems keliančius grèsmę kultūros ir intelektualinius lyderius Kaune. 